\title{
EFEKTIVITAS MULTI SOIL LAYERING DALAM MEREDUKSI LIMBAH CAIR INDUSTRI KELAPA
}

\author{
Effectiveness Of Multi Soil Layering To Reduce \\ Coconut Industrial Liquid Waste
}

\author{
Adewirli Putra ${ }^{1}$, Wiya Elsa Fitri ${ }^{2}$ \\ ${ }^{1}$ Unversitas Mohammad Natsir, Bukittinggi \\ ${ }^{2}$ Stikes Syedza Saintika, Padang \\ email: adewirliputra@gmail.com
}

\begin{abstract}
Abstrak. Telah dilakukan penelitian untuk mengetahui kandungan cemaran limbah cair industri kelapa, hasil penelitian ini memperlihatkan bahwa konsentrasi senyawa cemaran yang terdapat pada limbah cair industri kelapa ini diatas ambang batas, oleh sebab itu perlu dilakukan pengolahan menggunakan metoda Multi Soil Layering. Tujuan penelitian ini untuk melihat efektifitas MSL dalam mereduksi limbah cair industri kelapa menjadi air layak minum. Hasil proses pengolahan limbah cair ini, dianalisa parameter terkait dengan baku mutu air layak minum, baik dalam proses aerasi maupun non aerasi dengan memvariasikan laju alir, parameter yang dianalisa antara lain $\mathrm{pH}$, Nitrit, Phospat, Sulfat, Klorida, $\mathrm{Mn}, \mathrm{Fe}$. Data yang diperoleh dari parameter yang tersebut diatas, dapat disimpulkan bahwa parameter yang di ujikan tersebut memenuhi standar baku mutu air minum sesuai dengan nilai standar baku mutu Kepmenkes RI No.492/Menkes/Per/IV/2010.
\end{abstract}

Kata kunci : Efektivitas, MSL, Limbah Cair, Industri Kelapa

A research has been conducted to find out the content of contamination of coconut industry liquid waste, the results of this study show that the concentration of contaminant compounds contained in coconut industry liquid waste is above the threshold, therefore it is necessary to do the processing using the Multi Soil Layering method. The purpose of this study was to see the effectiveness of MSL in reducing liquid waste from the coconut industry to potable water. The results of this wastewater treatment process are analyzed parameters related to drinking water quality standards, both in aeration and non-aeration processes by varying the flow rate, parameters analyzed include $\mathrm{pH}$, Nitrite, Phosphate, Sulfate, Chloride, Mn, Fe. Data obtained from the parameters mentioned above, it can be concluded that the tested parameters meet the drinking water quality standards in accordance with the standard quality standards of the Republic of Indonesia Minister of Health No.492 / Menkes / Per / IV / 2010.

Keyword : Effectiveness, MSL, Liquid Waste, Coconut Industry 


\section{PENDAHULUAN}

Indonesia merupakan negara kepulauan, sepanjang pesisir banyak di tumbuhi kelapa yang merupakan tanaman tropis yang telah lama dikenal masyarakat Indonesia. Luas area produksi kelapa pada 20163.544 .002 hektare dengan total produksi kelapa Indonesia mencapai 18,3 juta ton dan ini merupakan yang tertinggi di dunia pada tahun 2016 dan mengungguli filipina dan India (Warta Ekspor - Edisi September 2017).

Sumatera Barat merupakan provinsi yang terletak di daerah pesisir sehingga sebagian besar wilayahnya banyak menghasilkan kelapa, dengan tingginya ketersediaan bahan baku kelapa, memungkinkan berdirinya industri pengolahan kelapa. Industri pengolahan kelapa adalah usaha dan/atau kegiatan di bidang pengolahan kelapa untuk dijadikan produk santan, produk tepung, minyak goreng kelapa, dan/atau produk olahan lainnya yang digunakan untuk konsumsi manusia dan pakan (Marlina, 2017)

Disamping produk minyak goreng dan santan yang dihasilkan, ada beberapa produk samping yang sesungguhnya tidak diharapkan oleh para pengusaha yaitu limbah. Beberapa produk limbah sudah dapat dimanfaatkan dan memiliki nilai ekonomis, seperti: endapan minyak yang disebut keteg sebagai bahan dasar makanan ringan, air kelapa sebagai bahan dasar nata de coco, dan daging buah sebagai bahan baku kopra dan coconut cream, dan lain-lain. Namun masih ada limbah dari proses produksi yang hingga saat ini masih belum tertangani dan mendapat solusi terbaik yang memiliki potensi besar dalam mencemari lingkungan, bahkan dampak negatifnya sudah banyak dikeluhkan masyarakat dan lingkungan sekitar industri saat ini (Hartono, 2016) dan (Marlina, 2017)

Limbah cair industri kelapa merupakan produk yang terbawa pada saat proses pencucian sewaktu proses produksi berjalan. Limbah cair industri kelapa banyak mengandung senyawa organik dan anorganik. Senyawa organik lebih mudah mengalami pemecahan dibandingkan senyawa anorganik. Senyawa organik dapat dirombak oleh bakteri baik secara aerob maupun anaerob. Kesulitan limbah untuk dirombak berpengaruh terhadap kelestarian lingkungan (beban pencemaran) (Supijanto, 2017).

Permasalahan ini telah menjadi perhatian penting, tidak terkecuali di Indonesia dan Sumatera Barat khususnya, karena banyak industri di Sumatera Barat yang belum bahkan tidak mematuhi aturan pengelolaan air limbah. Pada umumnya industri tersebut hanya langsung dibuang ke badan peraian/sungai tanpa diolah terlebih dahulu, sehingga dapat menurunkan kualitas air sungai tersebut.

Metoda MSL adalah salah satu metoda pengolahan air limbah yang memanfaatkan tanah sebagai media utama dengan cara mempertinggi fungsinya melalui struktur, yang dibentuk dalam sebuah konstruksi berupa lapisan campuran tanah dengan material organik, karbon dan material lainnya seperti serbuk besi dengan lapisan batuan (zeolit, perlit, dan kerikil atau tergantung pada jenis batuan yang tersedia) dalam bentuk susunan batu bata (Putra, et.al. 2018; Masunaga et al., 2010; dan Chen et al., 2009)

Secara prinsipil metoda MSL terdiri atas dua zona pengolahan utama yaitu zona aerob dan anaerob. Zona aerob terdapat pada lapisan zeolit (batuan) dan ruang antara lapisan zeolit dan blok campuran tanah. Zona anaerob terdapat pada lapisan campuran tanah. Proses pengolahan limbah cair dalam MSL terdiri atas dekomposisi, fiksasi, nitrifikasi, denitrifikasi, filtrasi, adsorpsi, dan absorpsi (An et al., 2016)

Dari beberapa penelitian yang telah dilakukan membuktikan bahwa metoda MSL cukup efektif digunakan dalam mengolah limbah cair domestik, air sungai 
tercemar dan limbah cair industri seperti limbah cair industri santan kelapa (Putra et $a l, 2018$ ), limbah minyak goreng (Salmariza, 2017), limbah cair kelapa sawit (Mutia et al., 2015), limbah cair hotel (Elystia, 2012).

Tujuan dari penelitian ini adalah untuk mengetahui efektivitas Multi Soil Layering dalam mereduksi limbah cair industri kelapa. Dari hasil penelitian ini diharapkan referensi pengolahan limbah cair industri kelapa dan limbah cair yang telah melalui proses pengolahan ini tidak langsung dilepas kelingkungan namun dapat dimanfaatkan lagi dalam proses produksi di industri.

\section{METODE PENELITIAN}

\section{Alat}

Peralatan yang digunakan pada penganalisaan dan pengolahan kualitas limbah cair industri kelapa ini, antara lain reaktor Multi Soil Layering (Putra, 2018), Spektofotometer UV-Vis, AAS, pH meter, timbangan, ayakan 25 mesh, peralatan gelas, diregen, aerator, Vacuum pump, Botol Sampel, Neraca Analitik.

\section{Bahan}

Bahan yang digunakan antara lain $\mathrm{H}_{2} \mathrm{SO}_{4} 98 \%$, Kalium hidrogen ptalat $\left(\mathrm{KHC}_{8} \mathrm{H}_{4} \mathrm{O}_{4}\right)$, Kalium dihidrogen Phosfat $\left(\mathrm{KH}_{2} \mathrm{PO}_{4}\right)$ Dinatrium hydrogen Phosfat $\left(\mathrm{Na}_{2} \mathrm{HPO}_{4}\right)$ Natrium hidrogen karbonat $\left(\mathrm{NaHCO}_{3}\right)$,Natrium karbonat, Hidrazin Sulfat ,Heksa Metilen Tetramin, Ferro Ammonium Sulfat, Indikator Ferroin, Kalium Bikromat, Merkuri Sulfat, Perak Sulfat, $\mathrm{HCl}$ pekat, $\mathrm{Na}_{2} \mathrm{SO}_{4}$ anhidrat p.a, $\mathrm{MgCl}_{2} \cdot 6 \mathrm{H}_{2} \mathrm{O}$ p.a , $\mathrm{BaSO}_{4}$ p.a , Ammonium molibdat, $\mathrm{AgNO}_{3}, \mathrm{FeCl}_{3} \cdot 6 \mathrm{H}_{2} \mathrm{O}$ p.a, $\mathrm{MgSO}_{4} .7 \mathrm{H}_{2} \mathrm{O}, \mathrm{CaCl}_{2}$ anhidrat, air suling bebas sulfat (Aquabides), alkali azida, $\mathrm{MnSO}_{4}, \mathrm{Na}_{2} \mathrm{~S}_{2} \mathrm{O}_{3} 2 \mathrm{H}_{2} \mathrm{O}$, Amilum, $\mathrm{HNO}_{3}$ p.a, $\mathrm{K}_{2} \mathrm{CrO}_{4}, \mathrm{KI}, \mathrm{NaN}_{3}$.

\section{Tahapan Penelitian}

Penelitian ini merupakan penelitian lanjutan (Putra et al, 2018) beberapa tahapan dalam penelitian ini, antara lain tahapan pengambilan sample dan perlakuan sampel limbah cair segar sebagai sampel yang akan diukur konsentrasi polutannya.

Tahapan kedua pengaliran sampel kedalam reaktor MSL dengan dua kondisi, aerasi dan non aerasi,dengan memvariasikan laju alir dengan kecepatan 5,10,20,40 $\mathrm{ml} / \mathrm{menit}$.

Tahapan ketiga melakukan analisa kadar polutan yang yang terdapat dalam sampel setelah perlakuan, parameter yang di analisa antar lain penentuan $\mathrm{pH}$, konsentrasi $\operatorname{logam} \mathrm{Zn}, \mathrm{Fe}, \mathrm{Mn}$, hal ini dilakukan tiga kali pengulangan (Triplo).

Tingkat efisiensi dari proses tersebut dapat dihitung dengan menggunakan rumus

$\mathbf{E}=\{(\mathrm{A})-(\mathrm{B}) /(\mathrm{A})\} \times 100 \%$

Keterangan :

$\mathrm{E}=$ Efesiensi

$A=$ Konsentrasi sampel sebelum perlakuan

$\mathrm{B}=$ Konsentrasi sampel setelah perlakuan 


\section{HASIL PENELITIAN DAN PEMBAHASAN}

\section{Pengujian Limbah Cair Sebelum Perlakuan}

Kondisi limbah cair sebelum dilakukan proses pengolahan menggunakan MSL, maka dilakukan penentuan $\mathrm{pH}$, Phospat, Sulfat, Nitrit, Klorida, Mn, Fe dengan nilai seperti yang terlihat pada Tabel 1.

Tabel 1. Hasil Analisa Sampel Sebelum Perlakuan

\begin{tabular}{|c|c|c|c|c|}
\hline Parameter & Satuan & Limbah Cair & Metoda & $\begin{array}{l}\text { Baku } \\
\text { Mutu }\end{array}$ \\
\hline $\mathrm{pH}$ & & 5,5 & $\begin{array}{c}\text { SNI 06 - } \\
6989.11- \\
2004\end{array}$ & $6,5-8,5$ \\
\hline Phospat & $\mathrm{mg} / \mathrm{L}$ & 481 & $\begin{array}{l}\text { SNI 06 - } \\
6989.31- \\
2005 \\
\text { SNI } 06-\end{array}$ & * \\
\hline Nitrit & $\mathrm{mg} / \mathrm{L}$ & 0,14 & $\begin{array}{c}6989.9- \\
2004\end{array}$ & 3 \\
\hline Sulfat & $\mathrm{mg} / \mathrm{L}$ & 347 & $\begin{array}{c}\text { SNI 20-- } \\
6989-2009\end{array}$ & 250 \\
\hline Klorida & $\mathrm{mg} / \mathrm{L}$ & 317,9 & $\begin{array}{c}\text { SNI 19- } \\
6989-2009\end{array}$ & 250 \\
\hline Mn & $\mathrm{mg} / \mathrm{L}$ & 2,14 & $\begin{array}{c}\text { SNI 05-- } \\
6989-2009\end{array}$ & 0,4 \\
\hline $\mathrm{Fe}$ & $\mathrm{mg} / \mathrm{L}$ & 2,04 & $\begin{array}{c}\text { SNI } \\
\text { 6989.4:2009 }\end{array}$ & 0,3 \\
\hline
\end{tabular}

*) tidak ada nilai standar baku mutu Kepmenkes RI No.492/Menkes/Per/IV/2010

Dari Tabel 1, dapat dilihat bahwa karakteristik limbah cair yang belum diperlakukan, dari hasil analisa terlihat bahwa konsentrasi parameter yang di ukur bearada diatas standar baku mutu air minum (Kepmenkes No.492/MENKES/PER/IV/2010) yang telah ditetapkan oleh pemerintah. Parameter tersebut pada umumnya tidak memmenuhi standar baku mutu air minum, kecuali pada parameter Nitrit. Oleh sebab itu, maka diperlukan pengolahan terlebih dahulu agar limbah cair ini dapat dijadikan air layak minum, oleh karena itu penelitian ini dengan memanfaatkan metoda MSL diharapkan limbah cair industri ini dapat dijadikan air layak minum.

\subsection{Hasil Analisa Limbah Cair Setelah Perlakuan Aerasi dan Non-Aerasi pada Sistem MSL}

Berdasarkan hasil analisa limbah cair yang telah diperlakukan menggunakan sistem MSL dengan perlakuan aerasi dapat dilihat pada tabel 2 dan non-aerasi pada tabel 3 berikut. 
Tabel 2. Variasi Laju Alir Terhadap Parameter Pada Proses Aerasi

\begin{tabular}{|c|c|c|c|c|c|c|}
\hline \multirow{3}{*}{ Parameter } & \multirow{3}{*}{ Satuan } & \multirow{3}{*}{$\begin{array}{l}\text { Sebelum } \\
\text { Perlakuan }\end{array}$} & \multicolumn{4}{|c|}{ Konsentrasi Limbah Cair } \\
\hline & & & \multicolumn{4}{|c|}{$\begin{array}{c}\text { Setelah perlakuan dengan variasi laju } \\
\text { alir }\end{array}$} \\
\hline & & & $\begin{array}{c}5 \\
\mathrm{ml} / \mathrm{mnt}\end{array}$ & $\begin{array}{c}10 \\
\mathrm{ml} / \mathrm{mnt}\end{array}$ & $\begin{array}{c}20 \\
\mathrm{ml} / \mathrm{mnt}\end{array}$ & $\begin{array}{c}40 \\
\mathrm{ml} / \mathrm{mnt}\end{array}$ \\
\hline $\mathrm{pH}$ & & 5,50 & 7,18 & 6,86 & 6,96 & 7,24 \\
\hline Phospat & $\mathrm{mg} / \mathrm{L}$ & 481 & 0,95 & 1,93 & 2,02 & 3,46 \\
\hline Nitrit & $\mathrm{mg} / \mathrm{L}$ & 0,14 & 0,046 & 0,041 & 0,046 & 0,034 \\
\hline Sulfat & $\mathrm{mg} / \mathrm{L}$ & 347 & 8,75 & 8,87 & 8,73 & 10,5 \\
\hline Klorida & $\mathrm{mg} / \mathrm{L}$ & 317,9 & 46,05 & 72,08 & 74,08 & 78,09 \\
\hline $\mathrm{Mn}$ & $\mathrm{mg} / \mathrm{L}$ & 2,14 & 0,44 & 0,12 & 0,27 & 0,2 \\
\hline $\mathrm{Fe}$ & $\mathrm{mg} / \mathrm{L}$ & 2,04 & 0,051 & 0,07 & 0,094 & 0,161 \\
\hline
\end{tabular}

Tabel 3. Variasi Laju Alir Terhadap Parameter Pada Proses Non-Aerasi

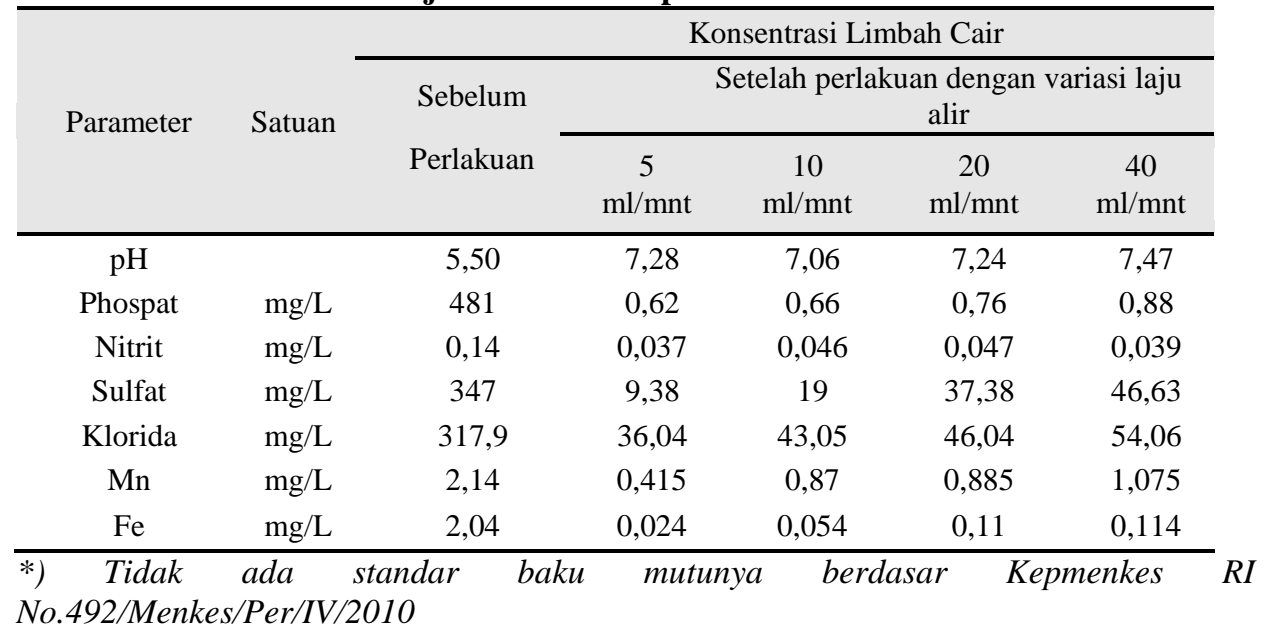

Berdasarkan hasil analisa setiap parameter pada laju alir 5, 10, 20 dan $40 \mathrm{ml} / \mathrm{mnt}$ dengan metode aerasi dan non-aerasi pada sistem MSL dari Table 2 dan 3, dapat ditentukan nilai efisiensi masing-masing parameter seperti dijelaskan berikut 
Tabel 4. Efesiensi MSL dengan variasi laju alir terhadap parameter pada proses aerasi

\begin{tabular}{ccccc}
\hline & \multicolumn{4}{c}{ Efesiensi MSL } \\
\cline { 2 - 5 } Paramet & \multicolumn{4}{c}{ Setelah perlakuan dengan variasi laju alir } \\
\cline { 2 - 5 } er & 5 & 10 & 20 & 40 \\
& $\mathrm{ml} / \mathrm{m}$ & $\mathrm{ml} / \mathrm{m}$ & $\mathrm{ml} / \mathrm{m}$ & $\mathrm{ml} / \mathrm{m}$ \\
$\mathrm{nt}$ & $\mathrm{nt}$ & $\mathrm{nt}$ & $\mathrm{nt}$ \\
\hline Phospat & 99,80 & 99,60 & 99,58 & 99,28 \\
Nitrit & 68,06 & 71,53 & 68,06 & 76,39 \\
Sulfat & 97,48 & 97,44 & 97,48 & 96,97 \\
Klorida & 85,51 & 77,33 & 76,70 & 75,44 \\
Mn & 79,44 & 94,39 & 87,38 & 90,65 \\
Fe & 97,50 & 96,57 & 95,39 & 92,11 \\
\hline
\end{tabular}

Tabel 5. Efesiensi MSL dengan variasi laju alir terhadap parameter pada proses non-aerasi

\begin{tabular}{ccccc}
\hline & \multicolumn{4}{c}{ Efesiensi MSL } \\
\cline { 2 - 5 } Parameter & \multicolumn{4}{c}{ Setelah perlakuan dengan variasi laju alir } \\
\cline { 2 - 5 } & $\begin{array}{c}5 \\
\mathrm{ml} / \mathrm{mnt}\end{array}$ & $\begin{array}{c}10 \\
\mathrm{ml} / \mathrm{mnt}\end{array}$ & $\begin{array}{c}20 \\
\mathrm{ml} / \mathrm{mnt}\end{array}$ & $\begin{array}{c}40 \\
\mathrm{ml} / \mathrm{mnt}\end{array}$ \\
\hline Phospat & 99,87 & 99,86 & 99,84 & 99,82 \\
Nitrit & 74,31 & 68,06 & 67,36 & 72,92 \\
Sulfat & 97,30 & 94,52 & 89,23 & 86,56 \\
Klorida & 88,66 & 86,46 & 85,52 & 82,99 \\
Mn & 80,61 & 59,35 & 58,64 & 49,77 \\
Fe & 98,82 & 97,35 & 94,61 & 94,41 \\
\hline
\end{tabular}

\subsection{1 $\mathrm{pH}$}

Pada Tabel 1, dapat dilihat bahwa $\mathrm{pH}$ limbah cair sebelum diperlakukan kedalam sistem MSL cendrung bersifat asam dengan nilai $\mathrm{pH}$ 5,5. Hal ini disebabkan tingginya kandungan asam lemak yang terlarut dalam limbah cair tersebut, karena limbah cair ini merupakan limbah cair dari industri pengolahan kelapa, secara tidak langsung kandungan asam lemak dari kelapa yang akan diolah tersebut akan terbawa selama proses pencucian dan pengolahan. Selain itu, hal ini juga disebabkan oleh tingginya kandungan zat organik didalam limbah tersebut, dimana zat organik ini, cendrung terdapat anion-anion terlarut bereaksi dengan ion $\mathrm{H}^{+}$yang terdapat didalam air, sehingga menyebabkan $\mathrm{pH}$ menjadi rendah dan bersifat asam (Ginting,2007).

Berdasarkan baku mutu air minum, $\mathrm{pH}$ air minum yang di perbolehkan 6.58.5, sedangkan nilai $\mathrm{pH}$ limbah cair sebelum diolah adalah 5,5. $\mathrm{pH}$ limbah cair industri ini, belum dapat dikategorikan air layak minum, karena bersifat asam. 


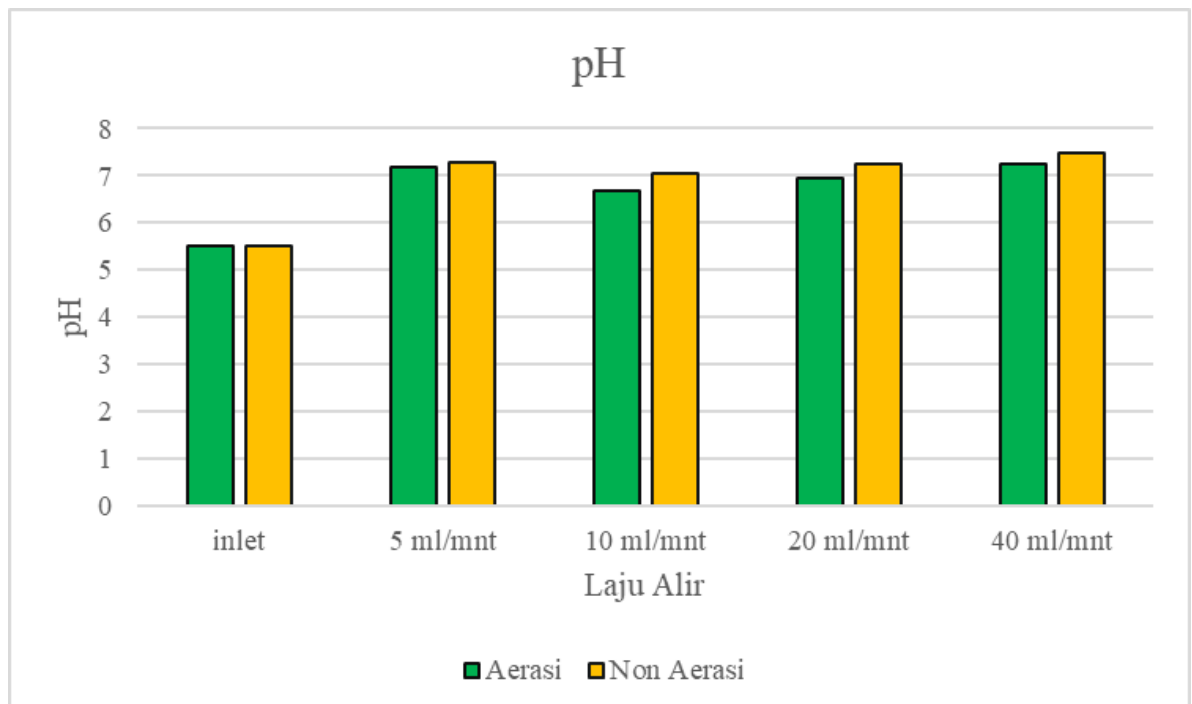

Gambar 1. Nilai pH sebelum dan setelah perlakuan dengan sistem MSL pada proses aerasi dan non-aerasi.

Setelah diperlakukan dengan sistem MSL pada proses aerasi dan non-aerasi, $\mathrm{pH}$ mengalami kenaikan dengan nilai berkisar 6,86 antara 7,47, rentang $\mathrm{pH}$ tersebut merupakan rentang $\mathrm{pH}$ netral. Hal ini diperkirakan asam lemak dan senyawa organik yang terlarut dalam limbah cair tersebut mengalami penguraian didalam sistem MSL oleh mikroorganisme selama proses pengaliran sampel, (Ginting, 2007). Pemakaian tanah Tanah Vulkanik yang disusun didalam sistem sehingga menciptakan kondisi anaerob. Tanah mempunyai kemampuan menetralkan $\mathrm{pH}$ karena adanya kandungan kation kation basa seperti $\mathrm{Ca}^{2+}, \mathrm{Mg}^{2+}, \mathrm{Na}^{+}, \mathrm{K}^{+}$dan kation asam seperti $\mathrm{H}^{+}$dan $\mathrm{Al}^{3+}$. Jika tanah dalam kondisi asam dapat terjadi pertukaran kation asam dengan kation basa dan sebaliknya. Adanya pertukaran kation tersebut menyebabkan terjadinya perubahan pH.(Herman, 2018)

\subsubsection{Phospat}

Kandungan Phospat dalam limbah cair sebelum dilewatkan ke sistem MSL adalah $481 \mathrm{mg} / \mathrm{L}$, dan setelah dilakukan pengolahan menggunakan sistem MSL pada proses aerasi, efisiensi penurunan phospat didalam limbah cair dengan variasi laju alir 5 , 10, 20, dan $40 \mathrm{ml} / \mathrm{mnt}$ yang masing-masingnya bernilai $99,80 \%, 99,60 \%$, 99,58 \%, dan $99,28 \%$

Pada proses non-aerasi dengan memvariasikan laju alir, terlihat terjadinya penurunan yang cukup signifikan terhadap kandungan Phosphat, dengan nilai efisiensi dari masing-masing laju alir 5, 10, 20, dan $40 \mathrm{ml} / \mathrm{mnt}$ adalah 99,87\%, 99,86\%, 99,84\%, $99,82 \%$ seperti yang terlihat pada gambar 2 .

Dari gambar tersebut terlihat bahwa penurunan phospat pada proses aerasi lebih rendah bila dibandingkan dengan proses non-aerasi. Hal ini sesuai dengan penelitian yang dilakukan oleh Sato et. al. (2005) yang melaporkan bahwa konsentrasi Phospat dari 
limbah cair yang diperlakukan dengan sistem MSL pada proses aerasi, lebih rendah dibandingkan dengan sistem MSL pada proses non-aerasi Penurunan pospat ini merupakan proses pertukaran ion yang terjadi didalam sistem MSL. Senyawa oksida besi, aluminium, dan mangan dapat membentuk lapisan pada partikel tanah yang dapat mengikat anion tertentu seperti Phospat. Senyawa-senyawa tersebut banyak terkandung didalam batuan perlit. Sebagai contoh, ion yang berperan dalam proses ini salah satunya ion $\mathrm{Fe}^{3+}$. Kadar $\mathrm{Fe}$ didalam sistem ini masih cukup tinggi. Disini ion $\mathrm{Fe}$ mengalami oksidasi menjadi ion $\mathrm{Fe}^{2+}$. Kemudian ion ini akan berpindah ke lapisan perlit dan mengalami oksidasi menjadi $\mathrm{Fe}^{3+}$. Ion $\mathrm{Fe}^{3+}$ inilah yang nantinya akan mengikat pospat didalam sistem MSL sehingga kadar pospat dalam limbah cair ini dapat diturunkan. Didalam sistem MSL, terjadi mekanisme penghilangan phospat yang terdiri dari proses adsorpsi fisika-kimia dan kontak antara limbah cair dengan lapisan tanah yang menjadi faktor utama dalam penurunan phospat, dengan keberadaan mikroorganisme pada lapisan tanah, dimana mikroorganisme ini dapat mengabsorpsi phospat sebagai nutrien pertumbuhannyadan mikroorganisme ini juga menghasilkan enzim yang dapat mengikat phospat dengan proses pertukaran ion (Wakatsuki et.al., 1993; Sato et.al., 2005; dan Herman, 2018).

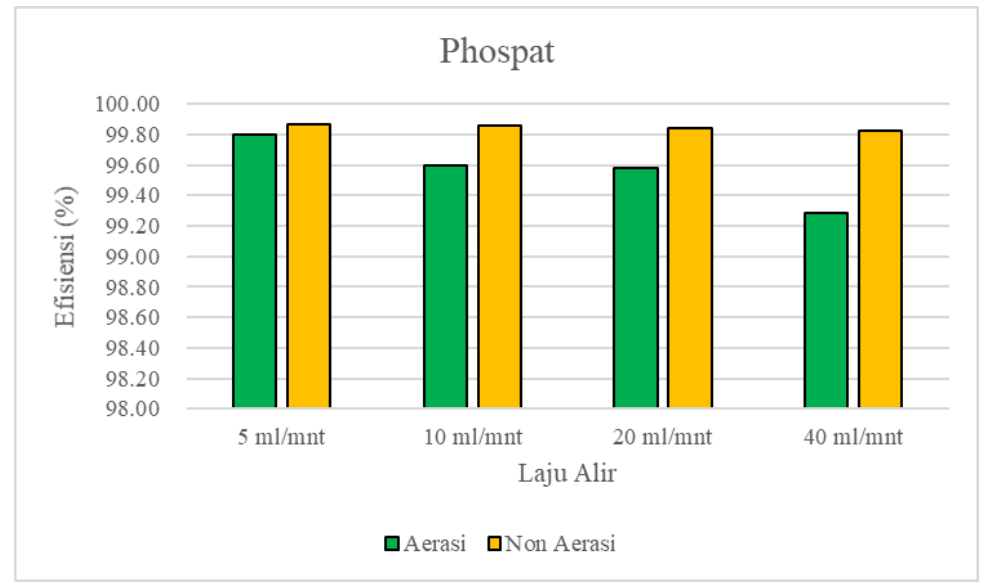

Gambar 2. Efisiensi MSL dengan variasi laju alir dalam mereduksi Phospat pada proses aerasi dan non-aerasi.

\subsubsection{Nitrit}

Kadar Nitrit yang diperbolehkan sebagai baku mutu air minum berdasarkan Kepmenkes No.492/MENKES/PER/IV/2010 adalah $3 \mathrm{mg} / \mathrm{L}$, pada limbah cair yang belum diolah dengan sistem MSL kadar dari nitrit yang diperoleh $0,144 \mathrm{mg} / \mathrm{L}$, maka kadar nitrit dalam limbah cair tersebut sudah memenuhi baku mutu air minum. Hal ini disebabkan oleh banyaknya mikroorganisme didalam limbah cair tersebut sehingga menyebabkan terjadinya proses denitifikasi senyawa organik yang terlarut didalamnya. Denitrifikasi merupakan proses yang paling penting untuk menurunkan kadar nitrat dan nitrit dalam limbah cair. Namun, tetap dilakukan analisa kadar nitrit untuk melihat 
efesiensi dari peralatan MSL yang baru dikonstruksi dalam proses penurunan kadar nitrit.

Dari gambar 3 terlihat bahwa pada proses aerasi diperoleh efisiensi dari masing-masing variasi laju alir sebesar $68,06 \%$ untuk $5 \mathrm{ml} / \mathrm{mnt}, 71,53 \%$ pada 10 $\mathrm{ml} / \mathrm{mnt}, 68,06 \%$ pada $20 \mathrm{ml} / \mathrm{mnt}$, dan 76,39 \% pada laju alir $40 \mathrm{ml} / \mathrm{mnt}$ (Tabel 4). Sedangkan pada non-aerasi efisiensi nitrit pada laju alir $5 \mathrm{ml} / \mathrm{mnt}$ senilai 74,31\%, 68,06 $\%$ pada laju alir $10 \mathrm{ml} / \mathrm{mnt}, 77,36 \%$ pada laju alir $20 \mathrm{ml} / \mathrm{mnt}$ dan 72,92\% untuk laju alir $40 \mathrm{ml} / \mathrm{mnt}$ (Tabel 5).

Penurunan kadar nitrit ini secara keseluruhan diperkirakan, karena proses nitrifikasi berlangsung dalam kondisi aerobik, di sini nitrit dioksidasi oleh bakteri Nitrobacter menjadi nitrat, dan kemudian nitrit dalam kondisi anaerob dapat direduksi menjadi nitrogen oleh bakteri anaerobik fakultatif seperti Achromobacter, Denitrobacillus, Nitrosococcus, atau Spirillum. Didalam sistem MSL tanah yang di campurkan sekam padi, dan arang merupakan sumber karbon bagi bakteri. Bakteribakteri ini bekerja dengan efektif sehingga proses denitrifikasi pada limbah cair dalam sistem MSL ini berjalan dengan baik. Tidak stabilnya kandungan nitrit yang diperoleh kemungkinan disebabkan oleh bentuk nitrit yang mudah berubah menjadi nitrat dalam limbah cair yang diolah, dan kemungkinan juga disebabkan karena total amoniak yang terurai menjadi nitrit dalam proses nitrifikasi sedikit jumlahnya, sehingga nitrit yang dihasilkan pun menjadi sedikit (Salmariza, 2008).

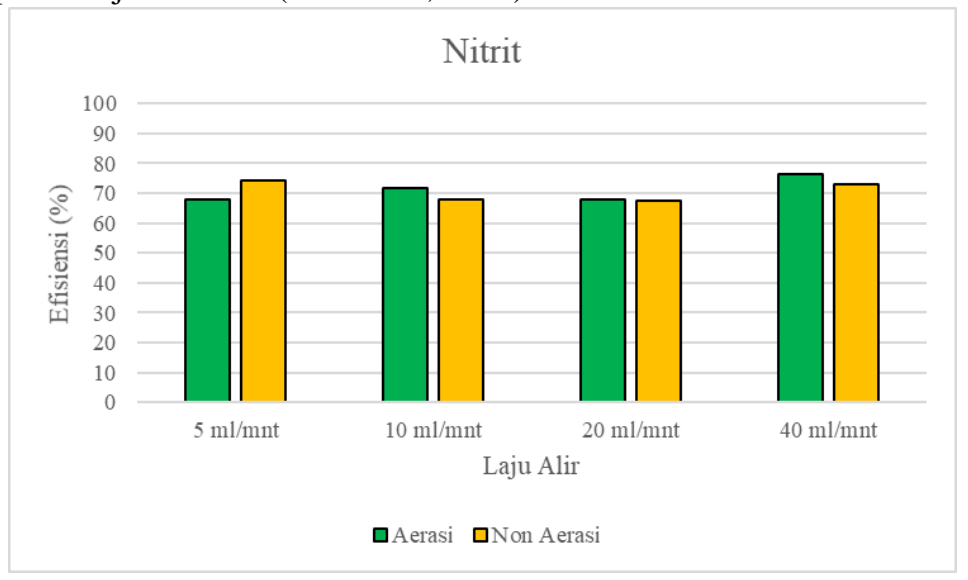

Gambar 3. Efisiensi MSL dengan variasi laju alir dalam mereduksi Nitrit pada proses aerasi dan non-aerasi.

Kecilnya konsentrasi nitrit yang terdeteksi pada efluen juga diperkirakan terganggunya proses nitrifikasi, karena $\mathrm{pH}$ influen yang rendah,menyebabkan proses penguraian ammonia total mejadi nitrit dan nitrat menjadi terhambat. Hal ini menyebabkan nitrit dan nitrat yang terbentuk pada proses nitrifikasi menjadi sedikit dan tidak stabil (Luanmanee, 2001). 


\subsubsection{Sulfat}

Dilihat dari hasil analisa, kadar Sulfat didalam limbah cair sebelum diolah sebesar $347 \mathrm{mg} / \mathrm{L}$, dimana kadar sulfat tersebut belum memenuhi kriteria air minum berdasarkan Kepmenkes No.492/MENKES/PER/IV/2010 yaitu $250 \mathrm{mg} / \mathrm{L}$. Untuk melihat efektifitas kerja dari peralatan MSL yang baru dikonstruksi, maka perlu diuji efisiensi dari peralatan MSL ini dalam menurunkan kandungan Sulfat yang dapat dilihat pada gambar 4 berikut.

Keadaan aerasi dan non-aerasi yang seimbang sangat mempengaruhi kualitas kerja MSL dalam menurunkan kadar sulfat dalam limbah cair. Penurunan kandungan sulfat dalam keadaan aerasi tidak memiliki perbedaan yang signifikan pada setiap material organik. Jika dilihat dari data keseluruhan bahwa kadar sulfat dalam perlakuan dengan proses aerasi dan non-aerasi berkurang hingga 97,48 \% dan 97,30\%.

Hal ini diperkirakan,karena terjadinya proses pertukaran ion melalui mikroorganisme seperti bakteri, kelompok bakteri yang dapat mereduksi sulfat adalah Desulfofibrio dan Desulfhoto maculum yang merupakan bakteri berbentuk spora (Widyati, 2007), dimana bakteri ini menghasilkan enzim, enzim yang dihasilkan, dapat menyerap ion sulfat.

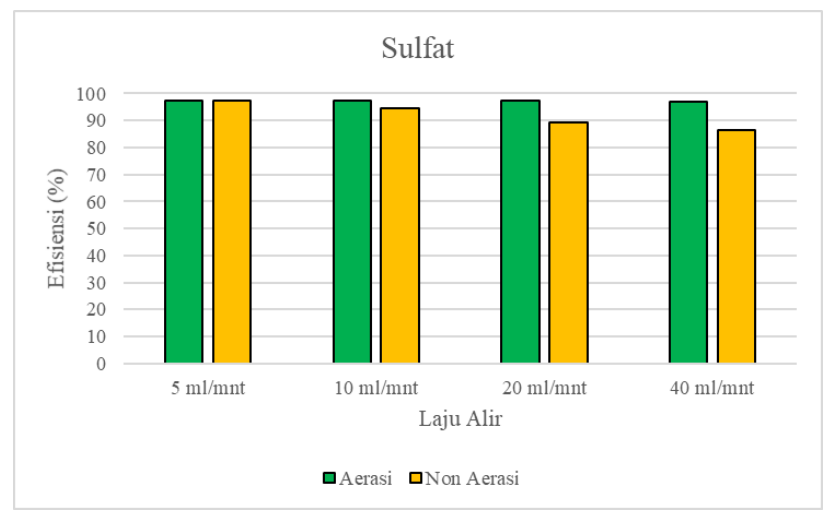

\section{Gambar 4. Efisiensi MSL dengan variasi laju alir dalam mereduksi Sulfat pada proses aerasi dan non-aerasi.}

\subsubsection{Klorida}

Kadar klorida yang diperbolehkan dalam baku mutu air minum $250 \mathrm{mg} / \mathrm{L}$, pada limbah cair yang belum diolah kadar klorida nya mencapai $317,9 \mathrm{mg} / \mathrm{L}$. Hal ini menandakan tingginya kadar klorida dalam limbah cair tersebut, hal ini mungkin dikarenakan, pada proses pencucian bahan baku (kelapa) mengalami kontak langsung dengan tangan manusia, dimana manusia merupakan salah satu penyumbang klorida berupa keringat yang merupakan hasil dari sekresi dan juga penggunaan desinfektan, dimana hal tersebut dapat menyebabkan terjadinya peningkatan kadar klorida pada limbah cair tersebut.

Dalam proses pengolahan limbah cair menggunakan metoda MSL terlihat bahwa motoda ini efisein dalam menurunkan kadar klorida didalam limbah cair tersebut, seperti 
yang terlihat dari gambar 5. Efisiensi penurunan klorida pada proses aerasi dan nonaerasi dengan variasi laju alir, nilai tertinggi ditemukan pada laju alir $5 \mathrm{ml} / \mathrm{mnt}$, yaitu mencapai $85,51 \%$ pada proses aerasi dan $88,66 \%$ pada non-aerasi.

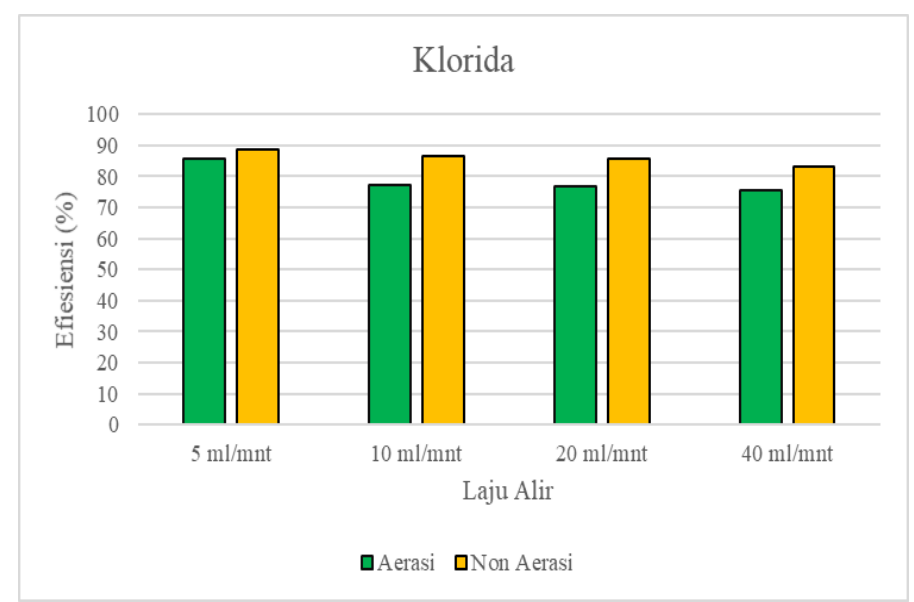

Gambar 5. Efisiensi MSL dengan variasi laju alir dalam mereduksi klorida pada proses aerasi dan non-aerasi

\subsubsection{Mn (Mangan)}

Keberadaan mangan didalam air menyebabkan timbulnya bau, rasa tidak enak pada air, serta menyebabkan warna air akan menghitam. Bersarkan peraturan menteri kesehatan tentang baku mutu air minum, kadar mangan dalam air minum yang di perbolehkan 0,4 $\mathrm{mg} / \mathrm{L}$. Dari hasil analisa terhadap limbah cair kadar mangan melebihi ambang batas, yaitu $2,14 \mathrm{mg} / \mathrm{L}$. Hal ini menandakan bahwa limbah cair ini perlu dilakukan pengolahan untuk menurunkan kadar mangan yang tinggi yang terkandung didalamnya, sehingga jika limbah cair ini dibuang ke lingkungan akan berbahaya dan belum layak digunakan untuk air minum.

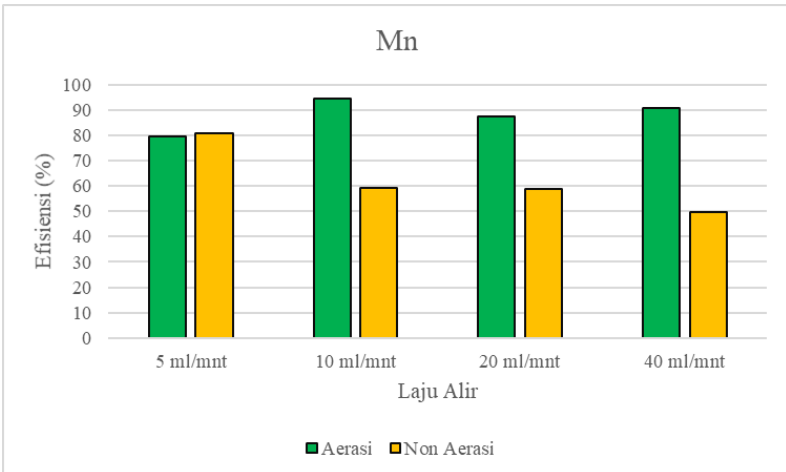

Gambar 6. Efisiensi MSL dengan variasi laju alir dalam mereduksi Mn pada proses aerasi dan non-aerasi 
Proses pengolahan limbah cair dengan menggunakan metoda MSL yang diperlakukan dengan 2 proses, yaitu aerasi dan non-aerasi dengan memvariasikan laju alir, seperti yang terlihat pada gambar 6, dapat menurunkan kadar mangan dalam limbah cair tersebut. Pada proses aerasi penurunan konsentrasi mangan dalam limbah cair efisiensinya mencapai 90,65 \% pada laju alir $10 \mathrm{ml} / \mathrm{mnt}$. Sedangkan pada proses nonaerasi efisiensi penurunan konsentrasi mangan mencapai $80,61 \%$ pada laju alir 5 $\mathrm{ml} / \mathrm{mnt}$.

Dari data tersebut, efisiensi penurunan konsentrasi mangan dalam limbah cair dapat dikategorikan baik, namun untuk standar baku mutu air minum dengan konsentrasi mangan dalam limbah cair setelah mengalami pengolahan belum layak untuk di jadikan sebagai air minum, dimana konsentrasi yang didapatkan setelah dilakukan pengolahan dengan metoda MSL dengan variasi laju alir $5 \mathrm{ml} / \mathrm{mnt}, 10 \mathrm{ml} / \mathrm{mnt}$, $20 \mathrm{ml} / \mathrm{mnt}, 40 \mathrm{ml} / \mathrm{mnt}$ dengan proses aerasi masing-masingnya $0,44 \mathrm{mg} / \mathrm{L}, 0,12 \mathrm{mg} / \mathrm{L}$, $0,27 \mathrm{mg} / \mathrm{L}, 0,2 \mathrm{mg} / \mathrm{L}$. Sedangkan pada proses non-aerasi dengan variasi laju alir 5 $\mathrm{mL} / \mathrm{mnt}, 10 \mathrm{~mL} / \mathrm{mnt}, 20 \mathrm{~mL} / \mathrm{mnt}, 40 \mathrm{~mL} / \mathrm{mnt}$, konsentrasi masing-masingnya 0,415 $\mathrm{mg} / \mathrm{L}, 0,87 \mathrm{mg} / \mathrm{L}, 0,885 \mathrm{mg} / \mathrm{L}, 1,075 \mathrm{mg} / \mathrm{L}$ (dapat dilihat pada Tabel 2 dan 3).

Keberadaan mangan didalam limbah cair berupa ion yang bervalensi $2\left(\mathrm{Mn}^{2+}\right)$ yang mana kation ini larut dalam air. Oleh karena itu, untuk mengurangi keberadaan mangan yang larut dalam air maka perlu dilakukan oksidasi untuk merobah mangan menjadi valensi yang lebih tinggi sehingga tidak dapat larut dalam air. Dari gambar 6, terlihat bahwa tingkat efisiensi penurunan mangan pada proses aerasi sangat baik 90,65 $\%$ bila dibandingkan dengan proses non-aerasi. Hal ini dikarenakan pada proses aerasi, pensuplaian udara kedalam sistem MSL mengakibatkan keberadaan ion mangan yang terlarut dalam limbah cair mengalami oksidasi membentuk ion mangan yang memiliki valensi yang lebih tinggi sehingga keberadaan ion mangan yang terlarut dalam limbah cair menjadi berkurang. Menurut (Adinda \& Elystia, 2015) Zona aerobik terjadi pada lapisan perlit dan permukaan campuran tanah. Ion logam yang terbawa bersama sampel akan menempel pada permukaan butiran perlit dan campuran tanah, dan selanjutnya akan diasorbsi oleh batuan perlit, tanah dan arang aktif. Perlit mempunyai pori-pori yang memungkinkan menyerap logam berat Mn.

\subsubsection{Fe (Besi)}

Kadar Fe sebelum perlakuan adalah $2,04 \mathrm{mg} / \mathrm{L}$ dan kadar maksimum yang diperbolehkan untuk air minum berdasarkan Kepmenkes RI No. 492 / MENKES / PER / IV / 2010 adalah 0,3 mg/L. Menurut Achmad (2004), Jika air mengandung kadar Fe di atas $0,3 \mathrm{mg} / \mathrm{L}$ maka dapat menyebabkan bekas karatan pada pakaian, porselen, dan rasa air menjadi tidak enak. Setelah limbah cair diperlakuan dengan sistem MSL dengan proses aerasi, kadar Fe turun menjadi $0,051-0,161 \mathrm{mg} / \mathrm{L}$ dengan tingkat efisiensinya 92,15 - 97,50\%, dan pada proses non-aerasi 0,024-0,141 mg/L dengan tingkat efisiensinya 94,41 - 98,82\%. Hasil yang diperoleh hampir sama dengan penelitian yang dilakukan oleh Syafnil (2008), kandungan Fe (Besi) yang terdapat dalam limbah cair dapat direduksi dengan menggunakan MSL(Multi Soil Layering).

Di lihat dari variasi laju alir 5, 10, 20, $40 \mathrm{ml} / \mathrm{mnt}$, baik untuk proses aerasi maupun non-aerasi, semakin tingginya laju alir mengakibatkan semakin berkurangnya efisiensi penurunan konsentrsi Fe. Hal ini dikarenakan jika laju alir semakin cepat maka 
waktu kontak sampel dengan material MSL akan berkurang sehingga proses adsorpsi Fe dan sidementasi dengan materil MSL semakin berkurang, memungkinkan tingkat efisiensi dari sistem MSL menurun (Syafnil, 2008).

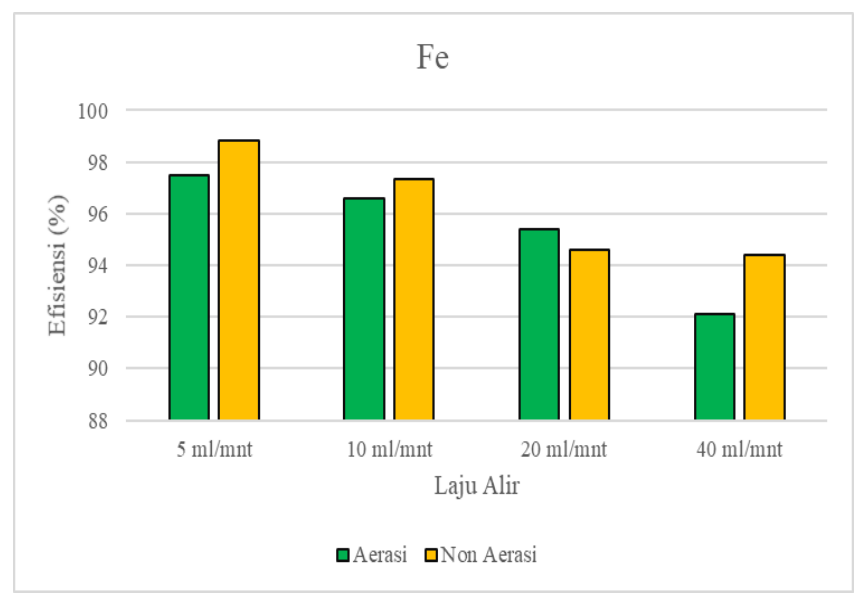

\section{Gambar 7. Efisiensi MSL dengan variasi laju alir dalam mereduksi Fe pada proses aerasi dan non-aerasi.}

Dari ke 2 proses perlakuan terlihat pola penurunan kadar Fe pada proses nonaerasi lebih bagus bila dibandingkan dengan proses aerasi. Dan dilihat dari hasil setelah pengolahan untuk parameter $\mathrm{Fe}$, dapat di kategorikan kedalam air layak minum sesuai standar baku mutu.

\section{SIMPULAN}

Metoda Multi Soil Layering dalam mereduksi limbah cair industri kelapa sangat efektif, namun untuk menjadikan limbah cair industri ini menjadi air layak minum sesuai dengan standar baku mutu air minum Kepmenkes RI No.492/Menkes/Per/IV/2010, dari hasil penelitian ini berdasarkan parameter yang diujikan sudah terpenuhi, namun berdasarkan parameter biologi (Putra, 2018) masih terdapatnya E.coli didalam sampel tersebut sehingga belum layak untuk dikonsumsi sebagai air minum, maupun di manfaatkan oleh industri di jadikan sebagai air untuk proses operational dan produksi. Sehingga perlu dilakukan penelitian lebih lanjut agar metoda ini efektif di jadikan salah satu metoda alternatif dalam pengolahan limbah cair industri kelapa menjadi air layak minum.

\section{DAFTAR RUJUKAN}

Adinda, T., Elystia, S., \& Edward, H. S. Metoda Multi Soil Layering dalam Pengolahan Air Gambut dengan Variasi Hydraulic Loading Rate dan Material Organik pada Lapisan Anaerob. Jurnal Online Mahasiswa Fakultas Teknik Universitas Riau, 2(1), 1-7. 
An, C.J., McBean, E., Huang, G.H., Yao, Y., Zhang, P., Chen, X.J., Li, Y.P., (2016). Multi-soil-layering systems for wastewater treatment in small and remote communities. J. Environ. Informatics 27, 131-144. doi:10.3808/jei.201500328

Chen, X., Luo, A.C., Sato, K., Wakatsuki, T., Masunaga, T., (2009). An introduction of a multi-soil-layering system: a novel green technology for wastewater treatment in rural areas. Water Environ. J. 23, 255-262. doi:10.1111/j.1747-6593.2008. 00143.x

Elystia, S. (2012). Efisiensi Metode Multi Soil Layering (MSL) dalam Penyisihan COD dari Limbah Cair Hotel (Studi Kasus: Hotel "X" Padang). Jurnal Teknik Lingkungan UNAND, 9 (2), 121-128

Ginting, P. 2007. Sistem Pengolahan lingkungan dan Limbah Industri. Bandung : Yrama Widya.

Hartono, Budi. (2016). Penerapan Sistem Daf (Dissolved Air Flotation) Untuk Pemisahan Limbah Minyak-Lemak Dalam Upaya Penerapan Konsep Zero Waste Pada Industri Minyak Kelapa (Cocos Nucifera). http://etd.repository.ugm.ac.id.

Herman, W., Darmawan, D., \& Gusnidar, G. (2017). Pemanfaatan Tanah Vulkanik dalam Sistem Multiple Soil Layering (MSL) Terhadap Pemurnian Air Irigasi Terpolusi. Jurnal BiBieT, 2(2), 49-59.

Luanmanee, S., Attanandana, T., Masunaga, T., and Wakatsuki, T. (2001) .The efficiency of a multi-soil-layering system on domestic wastewater treatment during the ninth and tenth years of operation. Ecological Engineering, 18: 185199.

Marlina, M., Wijayanti, D., Yudiastari, I. P., \& Safitri, L. (2018). Pembuatan Virgin Coconut Oil Dari Kelapa Hibrida Menggunakan Metode Penggaraman Dengan Nacl Dan Garam Dapur. Jurnal Chemurgy, 1(2), 7-12.

Masunaga, T., Sato, K., Mori, J., Shirahama, M., Kudo, H., Wakatsuki, T., et al. (2010). Characteristics Of Wastewater Treatment Using A Multi-Soil-Layering System In Relation To Wastewater Contamination Levels And Hydraulic Loading Rates. Soil Science And Plant Nutrition, 53 (2), 215-223.

Mutia, R. (2015). Metode Multi Soil Layering dalam Penyisihan Parameter (COD, TSS dan Amonia) Limbah cair kelapa sawit dengan variasi Hydraulic Loading Rate (HLR) dan material organik lapisan anaerob. Skripsi. Tidak dipublikasikan. Riau: Universitas Riau

Peraturan Menteri Kesehatan RI nomor 492/MENKES /PER/IV/2010. Hal. 6-9

Putra, A dkk. (2019). Efektivitas Penurunan TSS, BOD, COD, Dan E.Coli Limbah Cair Industri Santan Kelapa dengan Metode MSL (Multi Soil Layering) yang Dimodifikasi, Prosiding SENPLING 20181 (UNRI), 209-217

Salmariza, dkk., (2017). penggunaan metoda MSL untuk air limbah industri minyak goreng telah dilaporkan. Jurnal Litbang Industri. 7(1), 41-51.

Salmariza, Sy. (2008). Pengaruh variasi tingkat beban organic Dan laju alir terhadap efisiensi pengolahan air limbah industry tahu dengan reactor MSL. Buletin BIPD vol.XVI no.2.

Sato, Kuniaki, T. Masunaga, and T. Wakatsuki. (2005). Characterization of Treatment Processes and Machanism of COD, Phosphorus and Nitrogen Removal in a Multi-Soil-Layering System. Soil Sci. Plant Nutr., 51 (2), 213-221. 
Dalton : Jurnal Pendidikan Kimia dan Ilmu Kimia, Volume 2 Nomor 2, November 2019

Silalahi, B. M. (2017). Pengelolaan Limbah Kelapa Sawit (Elaeis guineensis Jacq.) di Angsana Estate, Kalimantan Selatan. Buletin Agrohorti, 5(3), 373-383.

SNI 05 - 6989 - 2009, Penentuan Logam Mangan

SNI 06 - 6989.11-2004, Penentuan pH

SNI 06 - 6989.31 - 2005, Penentuan Kadar Pospat

SNI 06 - 6989.9 - 2004, Penentuan Kadar Nitrit

SNI 19 - 6989 - 2009, Prosedur Pengujian Kadar Klorida

SNI 20 - 6989 - 2009, Prosedur Penentuan Sulfat

SNI 6989.4:2009, Prosedur Penenguan Kadar Fe secara AAS

Syafnil, S. (2008). Mereduksi Kandungan Fe (Besi) Dengan Metode Multi Soil Layering. GRADIEN: Jurnal Ilmiah MIPA, 4(2), 361-364.

Syafnil. (2008). Penggunaan Sistem Multi Soil Layering (MSL) Untuk Mereduksi Nilai BOD, COD, Kekeruhan, dan Kadar Fe dari Air Gambut. Tesis Program Pascasarjana Universitas Andalas.

Wakatsuki, T, et al. (1993). High Performance and N \& $\mathrm{P}$ removable On-Site Wastewater Treatment System by Multi Soil Layering Method. Water Science Technology, (27), 31- 40.

Warta Ekspor - Edisi September 2017

Widyati, E. (2007). The use of sulphate-reducing bacteria in bioremediation of ex-coal mining soil. Biodiversitas Journal of Biological Diversity, 8(4). 